\title{
Challenges of the urban peripheral landscapes
}

\author{
Desafios das paisagens periféricas urbanas
}

Catharina Pinheiro Cordeiro dos Santos Lima ${ }^{[0]}$, Caio Boucinhas ${ }^{[b]}$

[a] Universidade de São Paulo (USP), Faculdade de Arquitetura e Urbanismo (FAU), São Paulo, SP, Brasil

[b] FIAM FAAM Centro Universitário, São Paulo, SP, Brasil

\begin{abstract}
The peripheral regions of Sao Paulo reveal a profound contradiction in their landscapes - on the one hand, remnants of their original biophysical basis and, on the other, increasing pressure for the territory's occupation. The northwest sector of the periphery, for example, presents environmentally sensitive areas which are at the same time under great pressure for occupation by those who do so by choice (the property market) and those who have none (irregular and high-risk occupation). The poor inhabitants of these regions have increasingly organized themselves to achieve basic rights through community associations, social movements, and cultural groups ever since the recent re-democratization process in Brazil. It is precisely in these urban spaces, which are precarious in many ways, that significant subjectivities have emerged in participatory processes, expressing an awareness of environmental issues with an implicit desire for more humanized landscapes. These processes often include children and their teachers as protagonists. For thirteen years, the Landscape, Art and Culture Laboratory (LABPARC) of the Faculty of Architecture and Urbanism (FAU) at USP has been working with educators and children from municipal public schools, developing projects, research, and university extension work in the region. This article aims to discuss this experience with the objective of showing the gains achieved and the challenges that may arise within the perspective of a collective construction of the city, where urban interventions can be harmonized with water sources, streams, steep slopes, forests, and fauna.
\end{abstract}

Keywords: Landscape pedagogy. Peripheral landscapes. Participatory process. Public parks.

\section{Resumo}

As regiões periféricas da cidade de São Paulo revelam uma profunda contradição em suas paisagens - por um lado, remanescentes de sua base biofísica original e, por outro, uma crescente pressão pela ocupação do território. 0 setor noroeste da periferia, por exemplo, possui áreas ambientalmente sensíveis que, ao mesmo tempo encontram-se sob forte pressão por ocupação por aqueles que o fazem por opção (mercado imobiliário)

CPCSL is architect and Urban Planner, Universidade Federal do Rio Grande do Norte (UFRN); PhD in Architecture and Urban Planning, College of Architecture and Urbanism, Universidade de Sao Paulo (FAU-USP), e-mail: cathypinheiro@gmail.com CB is architect and Urban Planner, Universidade Federal de Minas Gerais (UFMG); PhD in Architecture and Urban Planning, College of Architecture and Urbanism, Universidade de Sao Paulo (FAU-USP), e-mail: cboucinhas@uol.com.br 
e aqueles que não possuem nenhuma (ocupação irregular e de alto risco). As populações pobres dessas regiões tem se organizado, de forma expressiva, para a obtenção de direitos fundamentais por meio de associações comunitárias, movimentos sociais e coletivos culturais, no recente processo de redemocratização do Brasil. E precisamente nesses espaços urbanos que são, muitas vezes precários, que em processos participativos, subjetividades tem aflorado, evidenciando uma sensibilização para as questões ambientais, com um desejo implícito por paisagens mais humanizadas. Esses processos contam, frequentemente com crianças e educadores como protagonistas. Por 13 anos o Laboratório Paisagem Arte e Cultura (LABPARC) da Faculdade de Arquitetura e Urbanismo da USP, tem trabalhado com os professores e estudantes das escolas públicas municipais, desenvolvendo projetos, pesquisas e trabalhos de extensão universitária, na região. Este artigo busca discutir essa experiência, apontando os ganhos alcançados, mas, também os desafios surgidos na perspectiva da construção coletiva da cidade, onde as intervenções urbanas possam vir a ser harmonizadas com suas nascentes, córregos, encostas ingremes, florestas e fauna.

Palavras-chave: Pedagogia da paisagem. Paisagens periféricas. Processo participativo. Parques públicos.

\section{Introduction}

Forgotten by public policies and even by the residents of central areas, the communities of the periphery of Sao Paulo, one of the world's most densely populated metropolises, are tightly squeezed in parts of the city often characterized as high-risk areas, resulting in socio-environmental tragedies with material and often human losses.

The rights of these inhabitants have been ignored by public policies, and only tend to be noticed by the media when individuals are involved in crime, or occupy areas on the margins of legality, or when social movements arise giving them a voice. In the minds of these forgotten people, they see themselves as living in a "periphery that isn't a "place", and where the poor are not seen as people", a phrase repeated in various community meetings, in participatory project workshops, and in various popular demonstrations. Such a perception of their own invisibility makes for a feeling among these populations of alienation from the life of the polis, corroborating their low self-esteem. It is equally common to hear phrases such as "I'm going to Sao Paulo", as if the periphery were an anti-city, far from, and outside the limits of the so-called formal city.

This is a two-way street set in the collective consciousness, since the time of the earliest forms of capitalism, finding its cruelest manifestations in the 21st century, with the advance of neo-liberalism; Guattari (2014, p. 31) suggests that even forms predating capitalism "[...] were not exempt from this predisposition to capitalize subjective power, both in the ranks of their elites and in those of their proletariats". In this way, by means of hegemonic forces, not only are real social inequalities produced, but also subjectivities are formed regarding this reality.

The northwest region of the city of Sao Paulo, in turn, is a mosaic with socio-environmental singularities and paradoxes constituting a challenge to architects, urbanists, landscape designers, geographers, and ecologists, among the many researchers and planners of urban space willing to search for socio-environmentally responsible answers to the planning and design of a city both more equitable and displaying greater equanimity.

On the one hand, the region comprises an environmentally sensitive area, where traces of the original biophysical basis remain legally protected as areas of permanent protection - APPs. In this landscape, characteristics of a primeval capillary fluvial system alternate and interconnect with many streams and wetlands (springs, marshes and alluvial plains), niches of luxuriant vegetation, important remnants of the Atlantic Rainforest (Jaraguá Park, the Serra da Cantareira hills and Anhanguera Park - Figure 1), significant native fauna, with undulating relief and steep slopes, as well as hilltops with exceptional views of the landscape.

At the same time, especially in the past thirty years, the region has witnessed a rapid process of occupation, through settlements often built by the people themselves in a collective effort, and housing projects built by state and municipal authorities to resettle populations 


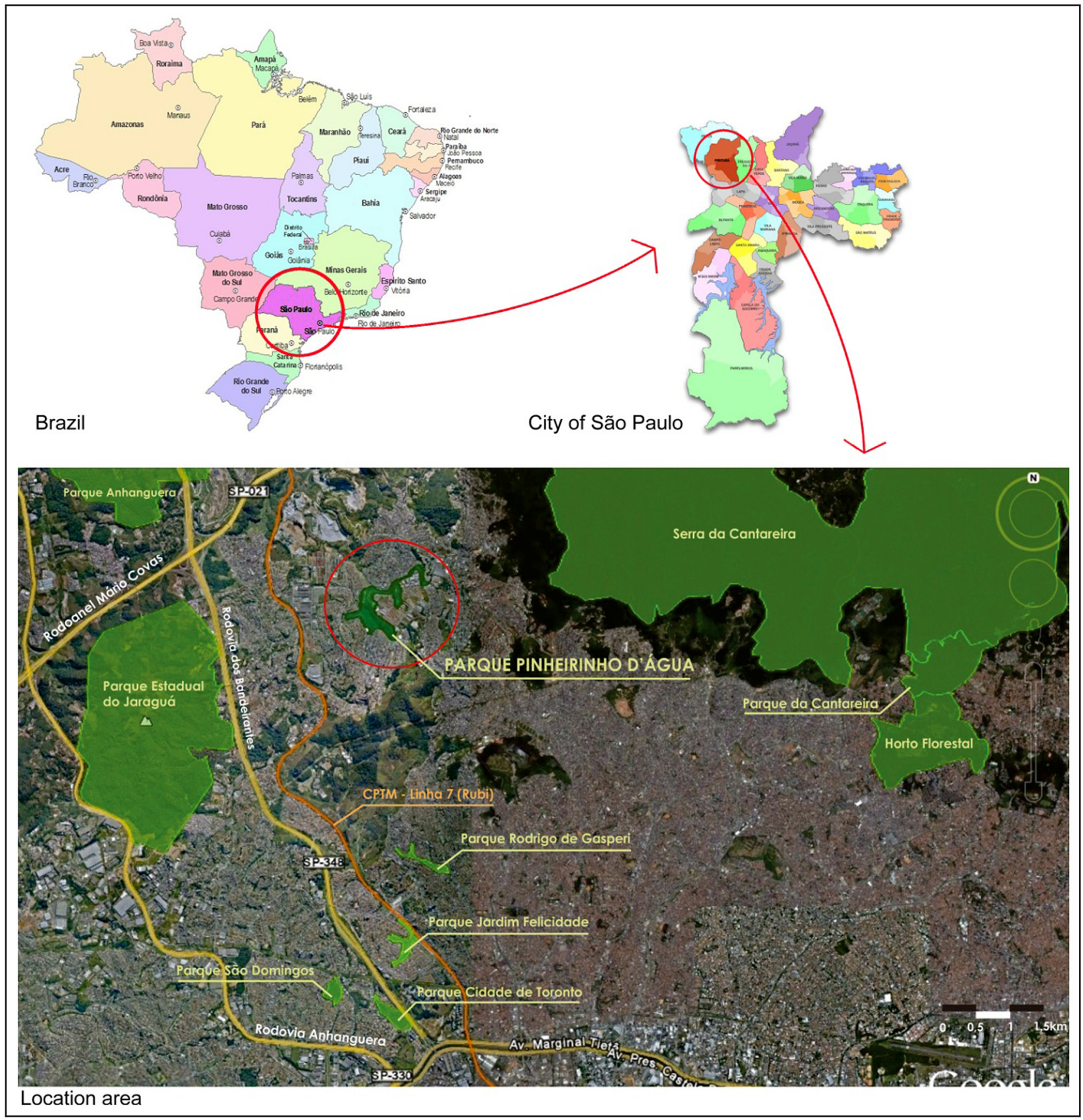

Figure 1 - Location area

Source: Drawn from the Instituto Brasileiro de Geografia e Estatística (IBGE, 2015) cartographic database and Google Earth aerial photo (Google Earth, 2015).

removed from more centrally-located favelas. These communities were regrouped in a dispersed manner, disregarding important everyday open spaces such as soccer playing fields, spaces sacrosanct for sport and leisure, normally the only flat and horizontal areas in the midst of dense occupation on steep slopes, contributing to the making of an ethnically and spatially heterogeneous mosaic that often does not see itself as having either a territorial or a community identity. In this occupation process, many areas considered to be "high risk" from the geotechnical viewpoint, with steep slopes, present worrying population densities, producing a dramatic landscape that challenges the canons of both architecture and engineering.

The area that includes the districts of Pirituba and Jaraguá, located on the northwest edge and the focus 
of this article, adds to this heterogeneity the remnants of rural and industrial environments, alternating in its landscape, traditional pastoral activities, active rock quarries, industrial plants, and more recently, condominiums built by a property market that puts pressure on the region for houses and apartment blocks for higher income groups.

In the dialectic of the landscape, this social mosaic exhibits its most unjust outlines when we consider the precarious nature of most housing, the absence of any basic infrastructure for sanitation, public educational equipment, culture, health, urban mobility, leisure, recreation, and safety; at the same time, we can see the permanence of a type of 'social eros' or 'group eros' to quote Guattari (2014) that insists on rejecting death and refuses to accept a fate that seems imposed and inexorable; this 'eros' reveals itself in the practice of resistance and coping mechanisms, expressed in social movements, cultural collectives, organized groups of educators and students, among many that could be mentioned, along with a lack of options and a welcoming environment that has led many adolescents to illegal and violent pursuits linked to drug trafficking (Boucinhas \& Lima, 2013).

It is this refusal to accept the disastrous conditions created by a perverse capitalist system that continues to reproduce its quotas of poverty in the periphery, people often so exhausted by arduous work and long travel times in the metropolis that make the struggle for the provision of quality public equipment difficult, held hostage by their demands for basic and immediate needs, such as health and housing. To them, the right to the city (Harvey, 2014) in the broadest and most libertarian meaning of the polis, seems denied, or at least inaccessible.

How to have the time and energy to assert a right to plazas, parks, accessible and tree-lined streets, a minimum possibility of enjoying an urban space, when houses, daycare centers, schools, health centers, sewers, a water supply, and sufficient family income are all lacking? The struggle for these public open spaces seems secondary when so many essential services are lacking. The contamination of subjectivity by a perception that rights can be primary or secondary is a real fact, and very commonly fostered by public agents in harmful political bargains, as it will be seen later.

Here we can ask the following questions:

- How to encourage among the periphery's inhabitants the idea that not only do they have the right to a healthy environment, etc. but also to a better urban habitat qualified by landscape projects?

- How to foster, using the ideas of thinkers such as Felix Guattari (2014), an ecology of subjectivities in which an inalienable right to a just and democratic city is posited, in which open public spaces for leisure, recreation, sport, culture, and mutual sharing are an essential human right?

- How to face the dehumanizing challenge of nefarious structural processes with tactics and strategies of resistance, even under unfavorable conditions?

These are the ideas and concerns that this article addresses, taking as a starting point the development of a struggle for a quality public park, in a process that has already lasted for over two decades in the district of Jaraguá, and which includes a plurality of players, with an emphasis on the participation of educators and child and adolescent students. The purpose of this article is to reflect critically on the rich process of social participation by local grassroots movements (the housing movement and the local state schools surrounding the park) in partnership with the University of Sao Paulo, in seeking to identify the conflicts, contradictions, and subjectivities in this process, and also its creative strength and potential for change. The article is structured as follows:

First, we introduce the central theme and the purpose of the study, showing how the desire for a public park came from the housing movement itself, adding over time state schools, the university, and the public authorities.

Secondly, we discuss the fragility of a participatory process in situations where social vulnerability imposes certain conditions resulting in decisions that sometimes compromise the democratic process underway.

In third place, we discuss the pro-active role of the public schools in partnership with the university in the requalification of the Park project.

In fourth place, we show the process as it worked in the transformation of the Pinheirinho d'Água into an 'educator park' and the collective efforts of the schools in maintaining the park "alive".

In fifth place, we discuss the challenges to critical reflection on the Park process, using as references the thinking of Felix Guattari and David Harvey, showing points of convergence in their recognition of contemporary urban social movements, and their 
divergences regarding the systemic reach of these movements.

Finally, we argue that the right to the city should also include the landscape as a qualifying instance of the urban space.

\section{The desire for a park in a story of resistance: a story of struggle and partnerships}

In the 1990s, a social movement for housing, appropriately called Vila Verde (Green Town), occupied an area known as Jardim Panamericano in the district of Jaraguá. Around it, there was a large open space with substantial vegetation-covered strips, steep slopes surrounding wet levels and springs and streams which incited everyone's imagination and dreams (Figure 2). As they occupied the area with houses built by mutirão (a process whereby houses are built with everyone's contribution, on a rotating basis), the new residents were progressively inspired by the beauty of the surrounding landscape, slowly planting the seeds of a desire for a public park. These people cared for the area over a ten-year period, making sure that no building debris, household waste, and earth were dumped in it.

After finishing the construction of their houses and with their right to housing achieved, ideas and dreams were mobilized to broaden this spectrum to further important social achievements; the movement's leaders stated in an interview that they wanted a more humanized city for all the residents of that neighborhood because, after all, "[...] living is

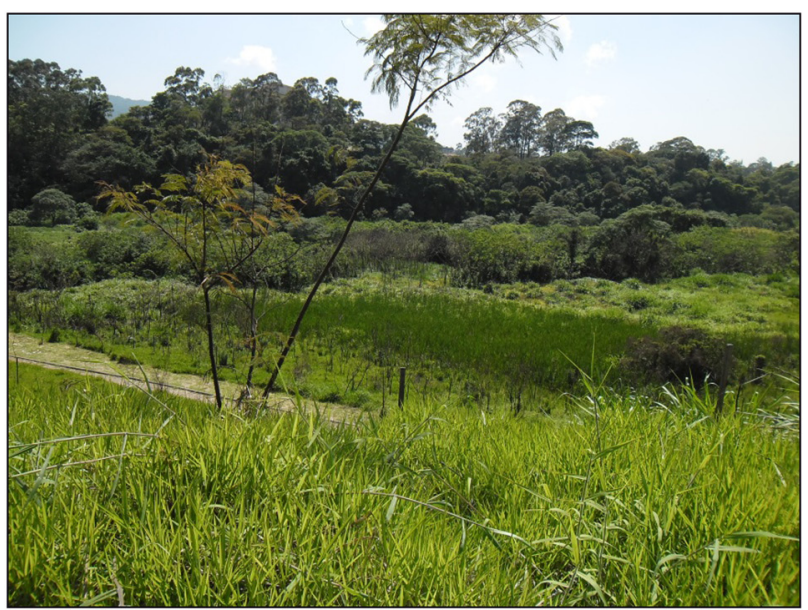

Figure 2 - View of the Pinheirinho d'Água Park in 2014 Source: Paula Martins Vicente. not just when you're inside your house [...]", expanding the scope of their demands and explicitly citing the concept of habitat, and not just habitation.

In 2000 , an area of $250,000 \mathrm{~m}^{2}$ was officially allocated as a municipal public park, crowning a further successful stage for the social movements and also expanding local people's participation in the development process of the park.

In an area adjoining the houses, and similarly facing the green area destined for the park, a Municipal Elementary School (EMEF - Rogê Ferreira), installed in a makeshift and provisional building, joined the movement, involving teachers and students in the construction of the park, with the support of the City's Municipal Department of Parks and Green Areas ${ }^{1}$.

In the process, this school, along with seven others in the region, involved students, teachers, and parents, and held a festive event aimed at choosing a name for the park. The schools presented a shortlist with eight names from which to choose in a popular vote by those attending; a stage was also set up with performances by local artists. This was a way of creating new links with the green area that was to be turned into a public park. The name chosen was Parque Pinheirinho d'Água (in honor of a marsh plant growing in the location) and an agreement made everyone responsible for the process of its implementation and management, as godparents to the Park. The party then continued.

In 2002, the College of Architecture and Urbanism at the University of Sao Paulo (FAU-USP) was invited to participate in the process of creating the park. Through the graduate course "Landscape Studies", the idea was to develop a whole democratic process of preparing plans that included an approach that would be broad and participatory (communities and local schools), inter-institutional (Municipal Departments of Green Areas and of the Environment, and FAU-USP), and interdisciplinary (students and consultants from various areas of knowledge). The idea of the collective

\footnotetext{
${ }^{1}$ The Department of Parks and Green Spaces is part of the Municipal Green Areas and Environment Secretariat (SMVMA).

${ }^{2}$ The subject was coordinated by FAU-USP professors with the participation of teachers and consultants from the areas of Education, Philosophy, Architecture and Urbanism, Forestry Engineering, Hydraulic Engineering, and Biology, as well as students/participants from other areas such as agronomy and anthropology. Prof. Henry Sanoff, from the University of North Carolina advised on the methodology of the participatory process.
} 

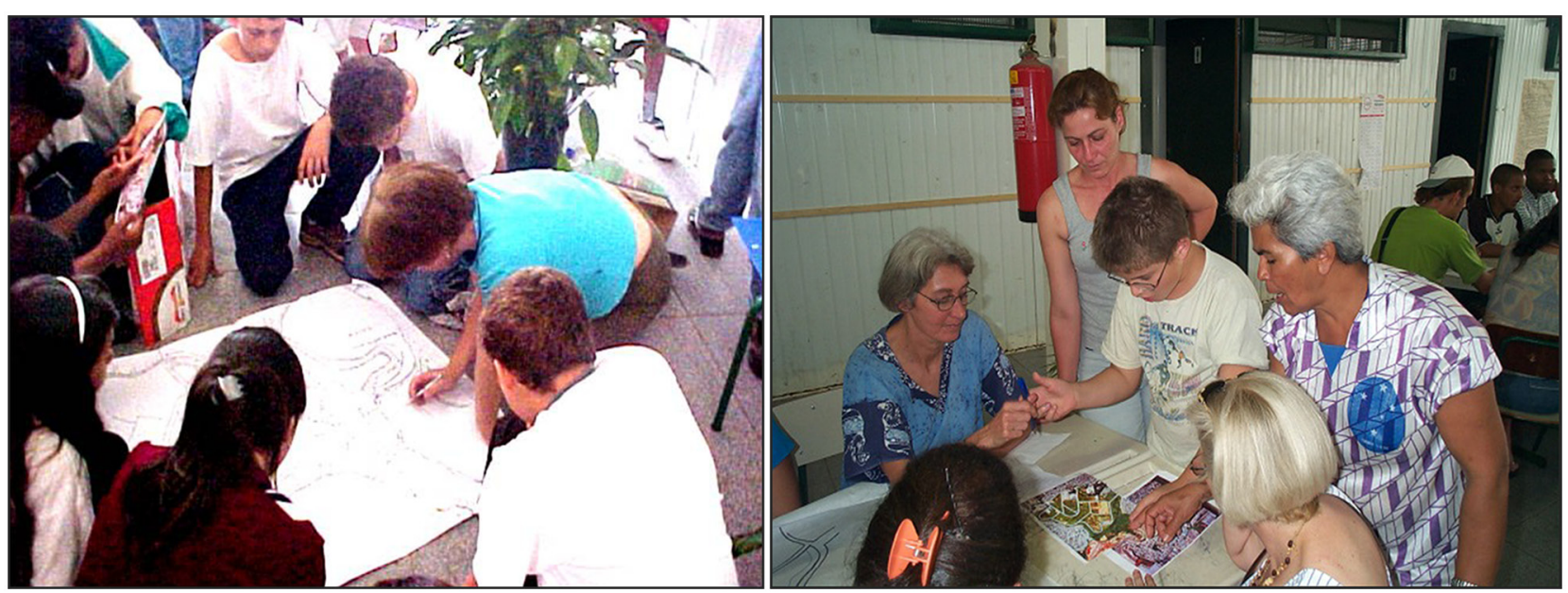

Figures 3 and 4 - Students and community representatives in project workshops

Source: Charrette 2002 archive, in LABPARC digital archive (USP, 2002).

construction of an empirical-theoretical knowledge basis guided the whole process, a condition favored by the educational institutions involved.

The engagement of the local population and schools in project workshops, field visits, environmental studies, and debates at the university resulted in an extraordinary collection of information on the wishes and demands that, once collated, constituted the park uses program (Figures 3 and 4). Worthy of note is that the children and adolescents accepted the task of interviewing their families, involving them in the process, and contributing equally important data for shaping decisions over the planning program.

This whole bank of data encouraged fruitful debate, broadening the scope of the discussions. Interdisciplinary groups of graduate students were consulted and, for a week during the semester, they were involved in an immersion workshop popularly known as Charrette, ${ }^{3}$ which resulted in four projects

\footnotetext{
${ }^{3}$ The term Charrette was first used in the $19^{\text {th }}$ century at the Ecole Nationale Superieure de Beaux Arts in Paris. It was a methodological procedure in which professors suggested to their Architecture students that they prepare a complex project to be conducted in a short period of time (usually a week) in the form of an immersion workshop. At the deadline, all of the projects were collected in a charrette (hand cart). "In the mid-1980s, in a nod to the creative activity of the architecture students, community development planners adopted the name [charrette] to describe interactive, multiday community planning sessions." (Lennertz \& Lutzenhiser, 2003, p. 4). In the state of Sao Paulo, the first interdisciplinary, interinstitutional and participatory charrette was held in May , 2001, in the city of Santo André, as the result of a
}

with shared conceptual and program affinities (decided in the participatory process), but which were innovative in their individual creative planning.

The Park's founding concept (guiding all the plans) had to be that of a "plaza-park"; the SMVMA (department of green areas) says that public parks under its jurisdiction must be fenced around and closed at night. Therefore, in order to make full use of the area for leisure and recreation for a population lacking both, all the plans worked with the idea of a large 'border of attractability' (a plaza) to surround the park, guaranteeing safe nocturnal use through public lighting. It would also provide the functions of a sort of muffler aimed at absorbing the impact of skateboarding, sports, etc., while safeguarding the ecologically sensitive inner area of the park (springs and streams, local flora and fauna).

\section{Conflicts and contradictions of the process}

In a process of discussion and harmonization of these ideas, inhabitants, SMVMA agents, and graduate students decided on a preliminary plan for the Pinheirinho d'Água Park, with more detail reserved for a further executive plan. (Figure 5).

partnership between the University of British Columbia (Center for Human Settlements, the James Taylor Chair in Landscape and Liveable Envionments), the municipality of Santo André, and the University of Sao Paulo - Faculty of Architecture and Urbanism, under the coordination of the authors of this article. (Luymes \& Proft, 2002). 


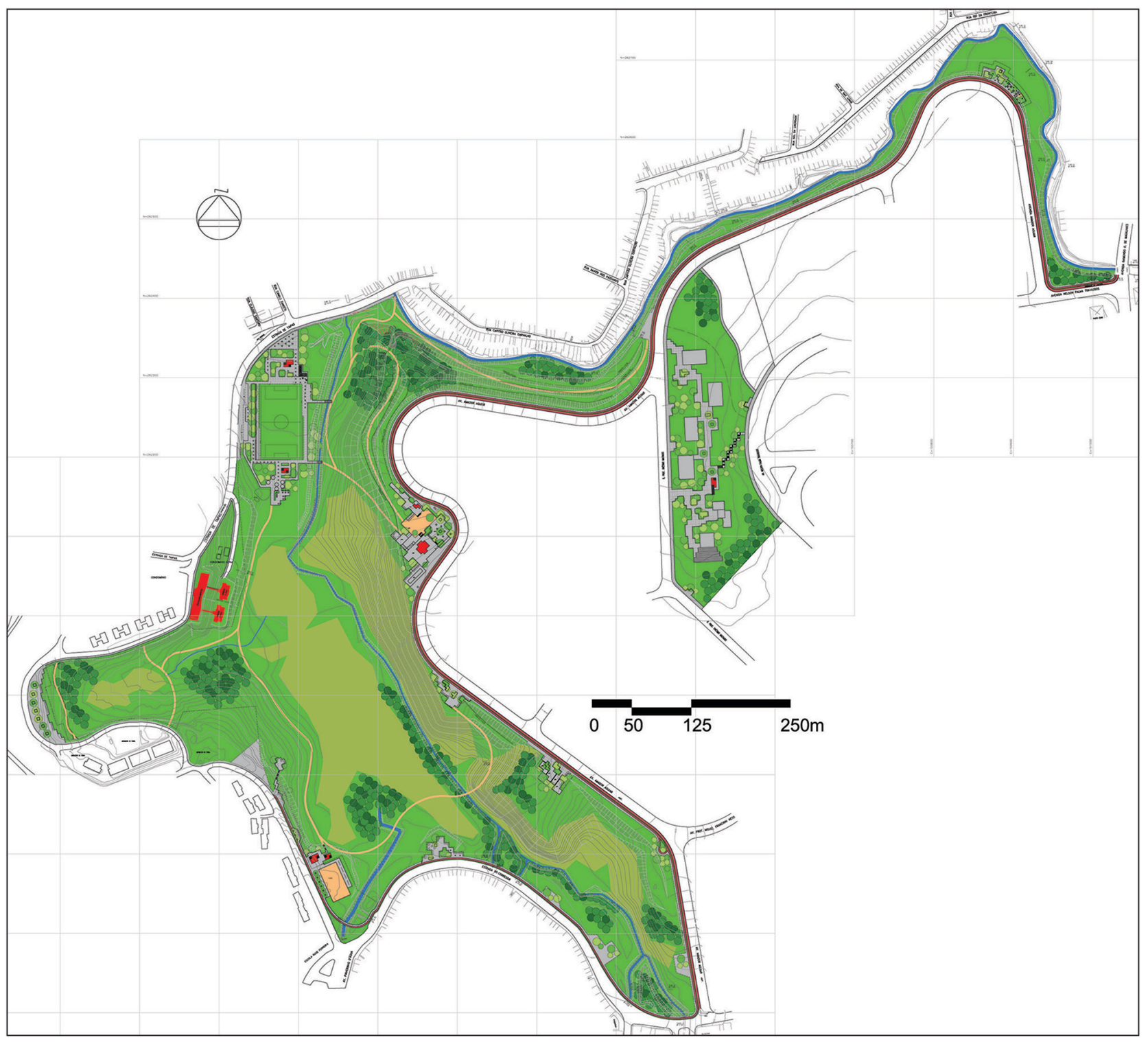

Figure 5 - Project implantation

Source: Raul Pereira Arquitetos Associados archive.

The Park was partially built, but unfortunately had its original plan significantly altered with the elimination of the large plaza embracing it, which was substituted by a narrow sidewalk with no equipment, running the risk of its appropriation.

In 2004, under pressure to build schools to replace the temporary and makeshift installations (containers made of aluminum siding, which were named "canned schools"), the City Hall, through state government departments, held a meeting in the region to announce the construction of a new school to replace the temporary EMEF - Rogê Ferreira, the protagonist in the struggle for the Park's creation.
Representatives from the City Hall argued that, due to the lack of suitable terrain in the surrounding area, the school could only be built within the area of the park, contrary to the whole democratic process of the plan preparation, which had set aside a large area for parties and celebrations and a community hall for meetings, courses, and the headquarters of the Park's Managing Council.

The need for a new school to supply the region's demand was unquestionable, but it did not seem legitimate to violate the long participatory process in which the people had established their choices; nor were those involved in the planning process even 
consulted to discuss their dissent in subjective, broader terms, as Guattari (2014, p. 33) suggests: "Rather than seeking a "cretinizing" and infantilizing consensus, the question in the future will be to cultivate dissent and an individual production of existence". In a frankly manipulative meeting, the authorities impelled a small group of the community to choose between "school" or "park as established in the planning process", giving the idea that they were mutually exclusive demands.

The EMEF - Rogê Ferreira was then built within the area of the park, eliminating one of its plazas on its edge. It also extended over the area bordering the Pinheirinho d'Água stream (APP), committing an environmental infraction in a clearly counter-educational way.

This episode is emblematic of prejudicial actions by the State in dealing with the environment and disrespecting democratically constituted processes; representatives of the residents, faced with the prospect of deciding between "school or park" as if they were mutually exclusive rights, took a position that was ambivalent and contradictory to their previous decisions; in their view, "[...] we had to win something so as not to lose everything [...]". The process shows the coercion exerted by the authorities for pragmatic ends (promises made during the campaign on the eve of elections) as well as jeopardizing continued collective decisions, highlighting the fragility of people's participation in a genuinely democratic process able to guarantee rights achieved and work on disagreement in other ways.

In addition, the intrinsic vulnerability of building public open spaces in Brazil should be emphasized. In the city of Sao Paulo, as in so many others, green areas and other similar spaces are seen by many public managers (and even by sectors of the population) as reserves of land for the construction of other public equipment (despite their recognized social value), or for religious purposes and even for housing. The Pinheirinho d'Água Park itself also has buildings of the Sao Paulo State's Urban Housing Development Company - CDHU within its borders (Figure 6).

As already suggested, parks and plazas are often seen as equipment to be built 'after' basic needs have been met; in Brazil, this is a very common view held by several public managers, mainly those who are linked to housing policies, but it is also part of the subjectivity of urban specialists and can be seen in the contradictions of the residents themselves contradicting their talk about 'habitat', when coerced to make decisions that involve lack of resources, often disrespecting the whole participatory and educational process underway. This issue requires deeper analysis of how subjectivities are constructed so as not to fall into the error of 'blaming' players who make decisions under coercion.

It must also be said that in addition to being considered as secondary or accessory, public open spaces often seem disconnected from other urban functions such as those in the areas of health and education. At a time when researchers are addressing ways of making cities healthier, open spaces beyond the environmental services supplied perform an extraordinary function in providing vegetation-covered areas with equipment able to be incorporated into public health promotion policies, including prevention and curing of the chronic illnesses that increasingly consume the State's budget. Meanwhile, a movement for Educator Cities has been launched in Barcelona advocating educational curricular actions in areas outside school buildings; a park, in itself, can represent a whole range of possibilities for greater contact with natural elements, for both esthetic fulfillment and promotion of health and learning.

\section{Openings for insurgency: spaces for hope}

Open the enclosed. The world of abstract labour is a world of enclosure, a world of physical and metaphorical walls.... Fight from the particular, fight from where we are, here and now. Create

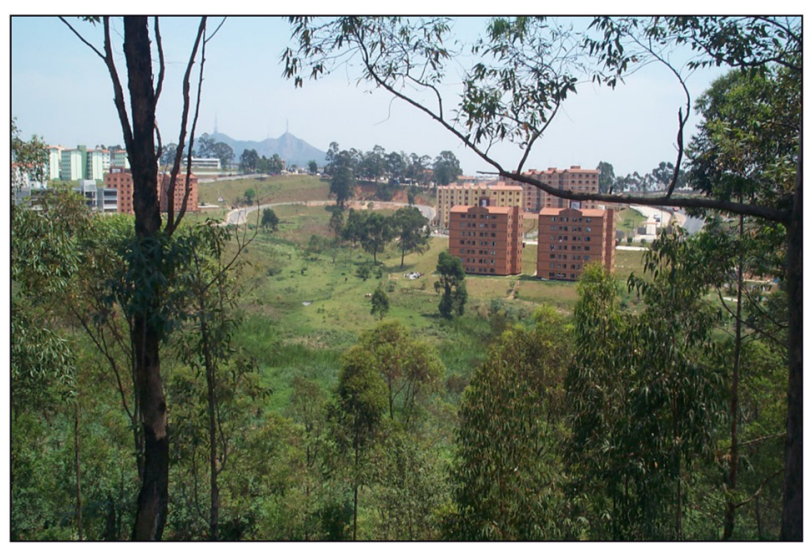

Figure 6 - Buildings of Sao Paulo State's Urban Housing Development Company within the Pinheirinho d'Água Park Source: Charrette 2002 archive, in LABPARC digital archive (USP, 2002). 
spaces or moments of otherness, spaces or moments that walk in the opposite direction, that do not fit in.... Our power to do things differently, our power to create a different world, is a flow that exerts a growing force against the walls that hem us in, a constant breaching of these walls. (Holloway, 2010, p. 260-261).

Since its partial and problematic construction in 2005, the Pinheirinho d'Água Park has suffered various assaults on its public patrimony: the occurrence of environmental crimes, such as the dumping of tons of earth and debris onto its marshland ${ }^{4}$; a nebulous action insufficiently clarified by the Prosecutor's Office so far; and even fires caused intentionally, judging from their pattern. With deteriorating trails and bridges, lack of maintenance of the vegetation and the absence of a security policy, the park has also become unsafe, a site of acts of urban violence and even murder ${ }^{5}$. All this leads to the construction of a subjectivity in which the park appears as abandoned - a "no-man's land" with inaccessible forest areas, feeding myths in the collective mind of the existence of dangers and wild animals (urban legends of giant snakes, for example).

In this partnership of public schools, the university, the local people, and public authorities, the latter two players have had their participation in the park's consolidation drastically reduced. The struggle to guarantee this equipment continued to be conducted by the region's municipal schools (in which the park continued to be an object desired by students and educators, as well as constituting a part of their political-pedagogical agendas) and by the public university (research, theses, dissertations, and other scientific works continued to be produced about the location). Also worth highlighting was the persistence of the Park Management Council, a body chosen by popular vote, which continued to demand action from the public authorities through meetings, protests, and publicizing through the print and TV media. In the words of Ana Sueli Ferreira, president of the Park Management Council: "Our Council is above all a group of popular resistance that fights for the urgent demands of the park and the people". ${ }^{6}$

\footnotetext{
${ }^{4}$ 2012, Minutes of the Park Management Council.

${ }^{5}$ 2015, Minutes of the Park Management Council.

${ }^{6}$ 2014, Interview recorded by Boucinhas and Lima.
}

In fact, even under the surface of hard reality in the urban periphery, as already suggested, the latency of a 'social eros' continues and occasionally breaks through this surface, showing through the cracks a desire to reverse socially unjust processes; these are the cracks of capitalism, to quote John Holloway (2010), situations in which it is possible to oppose hegemonic socio-economic processes, as Guattari (2014, p. 12) suggests, through the

[...] organization of micro-political and micro-social practices, new solidarities, a new lightness together with new esthetic practices and new analytical practices for the shaping of the unconscious.

Identifying them and giving them potential requires the cooperation of all those who optimistically believe in the possibilities of creating spaces for hope, of reversing imposed realities.

In 2012, an opportunity arose to take the partnership between the university and the EMEF Dep. Rogê Ferreira school community; this time, the idea was to propose a new joint project to conduct a political-pedagogical plan capable of working creatively on the potential of the school's presence within the park, including the mitigation (or partial reverse) of the impacts on the environment and landscape created by the school's construction. It was, to quote a popular saying often heard during this process, an attempt to "make a little go a long way". In any case, even with all its contradictions, the teaching possibilities of an educational and cultural institution situated in a public park are unimaginable, infinite.

In February 2012, the administration and teaching coordination at FAU-USP ${ }^{7}$ organized an experimental, political-pedagogical program involving the whole school, architects, city-planners, landscape architects, and architecture students to prepare a new project - that of a "School-Park". Using the means of the Charrette everyone was engaged in a week of immersion to manifest their desires and demands, prepare programs

\footnotetext{
${ }^{7}$ This work was coordinated by the FAU-USP Landscape Art and Culture Laboratory. It is almost impossible here to give credit to the great number of participants. From the viewpoint of the schools' participation, the actions of teachers Marcia Penha Resende, Elizabeth Toledo, and principle Fernando Mendonça deserve special mention, and in LABPARC FAU-USP, architects Raul Pereira, Paula Martins Vicente, and Vanessa Kawahira Chinen.
} 
and projects for spaces and buildings able to create new conditions for a more fluid relationship between school and park. It was possible to observe that, strategically, in establishing more physically concrete relationships, the school could be a new starting point for the process of re-appropriating the park.

During the week of this new Charrette, classes were suspended so that students and teachers could dedicate their time exclusively to the project. Everyone worked in an interdisciplinary manner (teachers of all disciplines - from sciences to Portuguese; from mathematics to physical education), constituting a challenge for educators who, in facing it, responded sensitively and creatively, overcoming natural initial difficulties. "Sensitizing workshops" were given, coordinated by architect Raul Pereira to encourage the emergence of educators' subjectivities and the warming up of ideas and energy for Charrette week.

Throughout the week-long immersion, a progressive and enthusiastic movement occurred, beginning with their recorded memories and their subsequent reading of the landscape in the field, continuing with manifestations of wishes and outlines of ideas, culminating in a cultural celebration with the participation of all those involved, as shown in the Figures 7 and 8.

These practices involving the Charrette methodology have proved to be very promising, according to the participants themselves. The articulation of the complexity involved (producing projects inter-, trans-, or supra- disciplinary around a common goal), with limited time for its realization in the form of complete immersion, seems to act as a catalyst in mobilizing ideas and desires, creating a ferment of collective idea sharing, both objective (pedagogical contents) and subjective (perceptions, affections, dreams). The construction of this new knowledge also results from the friction between the empirical and the theoretical, the specialized and the vernacular.

It should be emphasized that a school that is opened to experiments of this kind, necessarily has a progressive, pedagogical directorship and coordination, averse to an education that deposits knowledge or "banking education" in the words of educator and educational theoretician Paulo Freire (2004), and it is in tune with emancipatory, political-pedagogical practices.

Imagine what this therefore represents to the school's children and adolescents: the joy of freedom of bodily movement (repressed by the standardized construction of public educational system schools) in comings and goings, moving between the various classrooms and spaces, from the constructed to the natural, from the covered to the open horizon, from the school to the park and vice-versa. Add this to the fact that the school (for security reasons) is entirely surrounded by iron fencing, preventing a more casual connection with the park, which latter ends up forming in the children and adolescents' minds a source of freedom and endless creative and fun possibilities (Figure 9). The beautiful and mysterious landscape, with its wet, vegetation-covered horizons, easily seen from the school's windows and railings, provokes
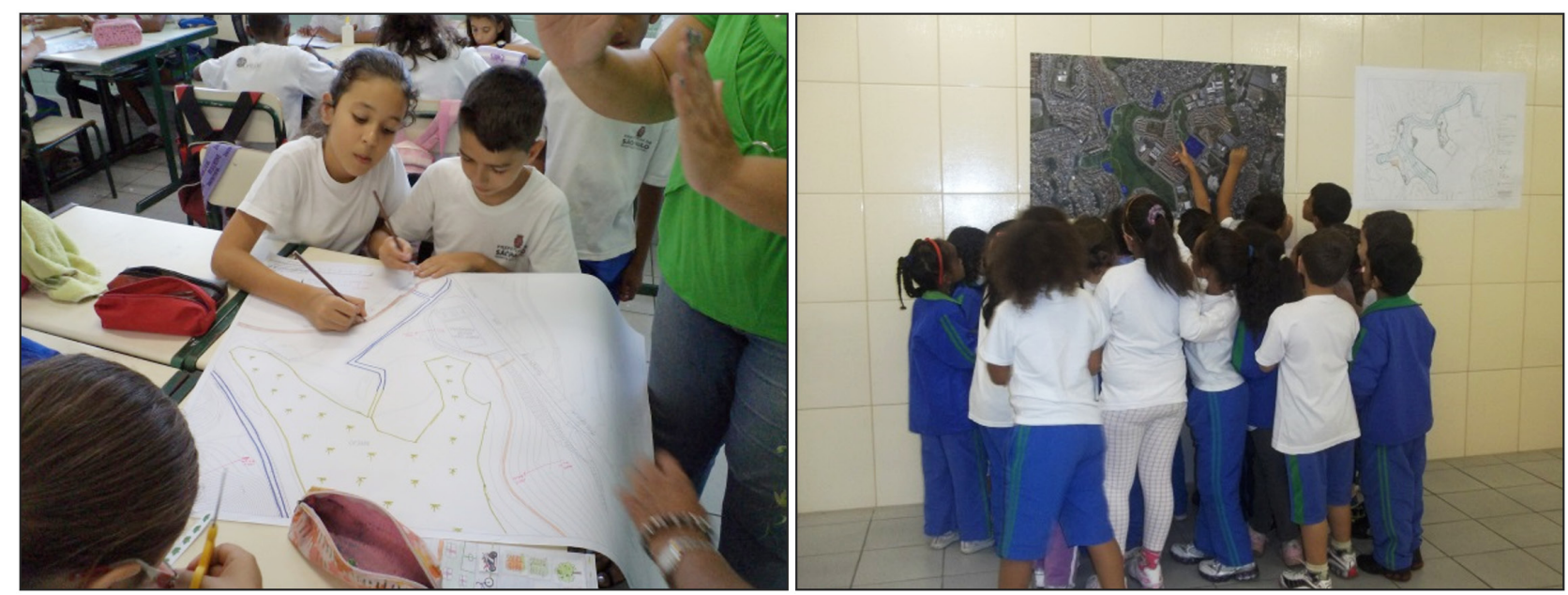

Figures 7 and 8 - Students during the week of the Charrette, 2012

Source: Paula Martins Vicente and Vanessa Rabelo. 


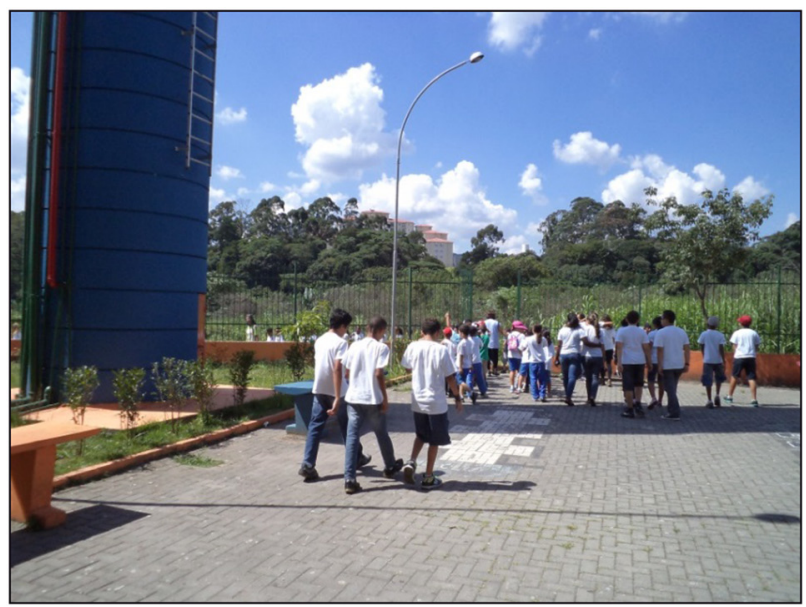

Figure 9 - Iron fencing preventing a more casual connection with the park Source: Paula Martins Vicente.

the imagination and desires of these children on a daily basis.

Not only the work's process demonstrated the extraordinary potential of the transversal didactic projects (beloved and strictly followed by the school's pedagogical strategy), uniting the whole teaching community in inventing projects, but also how surprising the work by the children and adolescents was. Over 2,000 projects from drawings (Figures 10 and 11), mock-ups, photos, texts, musical compositions, performances, etc. were collected and/or presented at the end of the Charrette in a festive party (celebratory rites - Figure 12). Art, as a pervasive and transversal example, made itself seen throughout the process in various manifestations, and during the party, teachers of various disciplines played a special part in organizing and leading popular dances and other manifestations.

The process of systemization and interpretation of the results required both the recurrence (quantitative) of the wishes and demands expressed, and the occurrence (qualitative) of individual expressions distinct from the majority.

The role of the children and adolescents should also be emphasized here in the choices that affected their living places, not just giving opinions in interviews and workshops, but also in effect appropriating an instrument usually limited to a restricted circle of specialists and presenting sensitive and creative answers. In this way, they have experienced the exercise of their citizens' rights early on, planning and influencing the projects that will affect their everyday lives, as the subjects of their own story.

With respect to the purposes of the Charrette, the results showed a clear understanding of the urban environment in detailed interpretations of the city, showing knowledge of the daily reality and the detection of social and urbanism problems - interpretations of those who are viscerally aware of the precariousness of public policies in various areas of life; they also revealed sensitivity and creativity in the relationships of the demands and desires for new equipment; the most frequently mentioned item was for the playground, but what really caught the attention was when they cited trees, flowers, trails, a wooded area for reading, a bird observatory, and other demands that alluded to a need for more direct contact with natural elements; the desire for an observatory for star-gazing is not only revealing of a grasp of poetry and the desire for knowledge of astronomy, but also evidence of a wish to use the park at night.

Another aspect worthy of note was the perception (without any prompting) that environmentally sensitive areas can be used for play as long as there are no harmful impacts; items such as a tree-house, zip lines and walkways to see the tree canopy, equipment that dispenses the need for contact with the ground. In summary, they demonstrated a great architectural and ecological intelligence in the creation of new equipment. At the week's end, it was common to hear the children and adolescents voice a wish to be architects.

For all the players that participated in the experience, in a subsequent evaluation meeting, the gain in learning was equally valuable. However, it is not only the gain in knowledge of the place's reality and sharing valuable information with children, adolescents, and their teachers that is valued. The Charrette experience had other meanings apart from that of just an exercise, albeit with an amazing databank; above all, what was gained in terms of human learning was a new collective ethos; in the experiencing of the phenomenon, when people are disarmed and give themselves to the joy of dreaming of changing the world, glances and emotions are shared, an ethic is developed forged in the doing, bringing a sense of empathy and solidarity, reverting calcified subjectivities, demolishing preconceived ideas, and creating conditions for the transformation of humans 

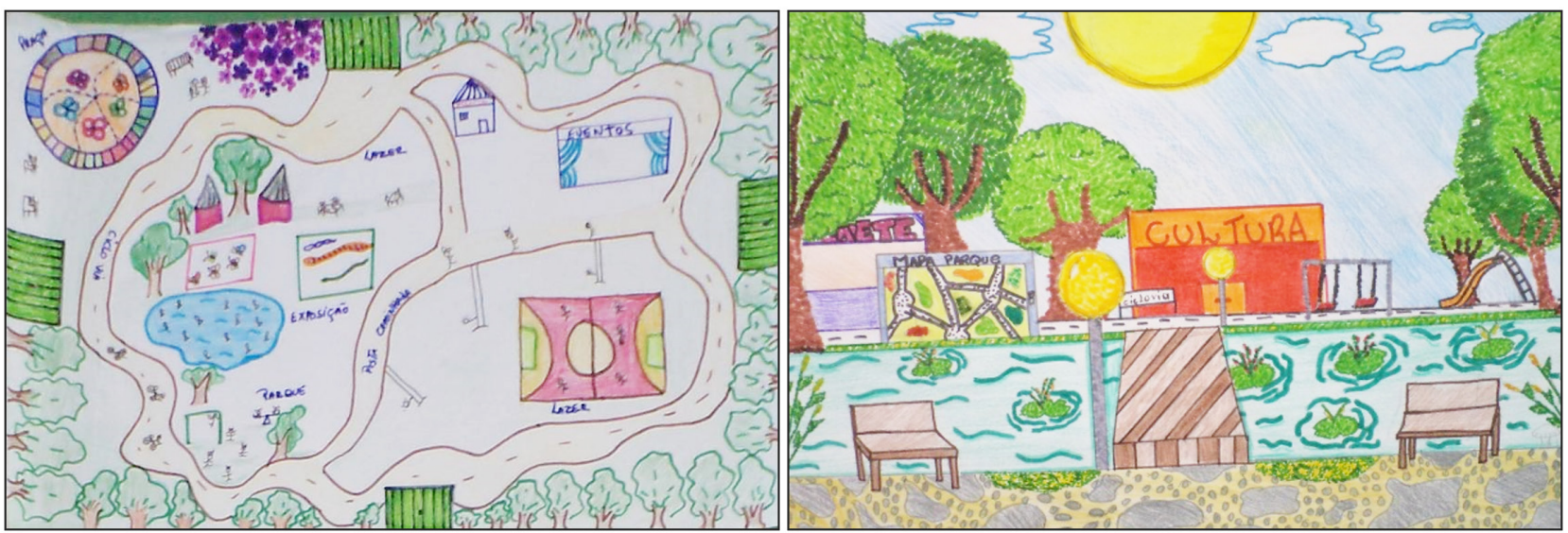

Figures 10 and 11 - Drawings produced by students during Charrefte 2012 Source: Paula Martins Vicente's archive.

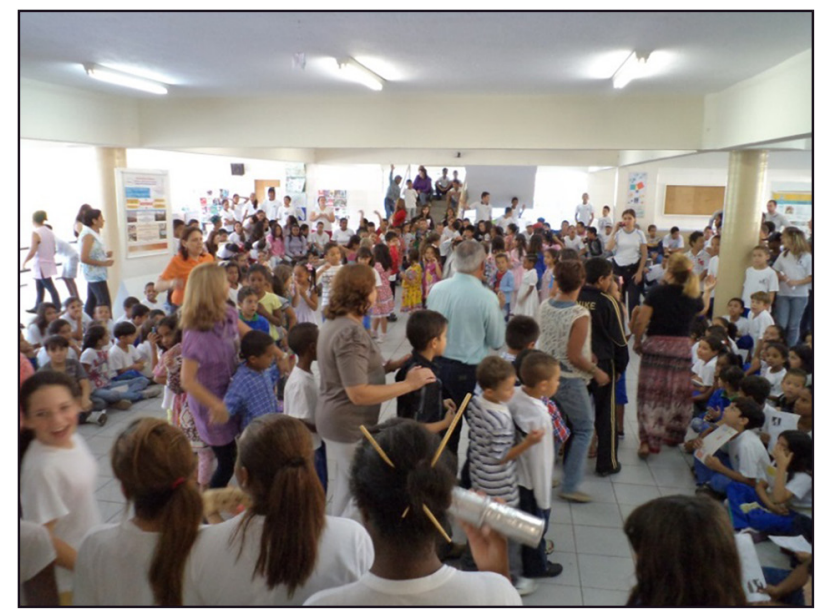

Figure 12 - Festive party at the end of the Charrette 2012 Source: Paula Martins Vicente's archive.

and their living spaces. In the words of Marcia Penha, geographer and teacher at Leonel Franca School ${ }^{8}$ :

The process has been enriching, because as we participate as collaborators in research projects with university students, we are nourished by new references brought by these partners and expand our repertoire. [...] The dialogue with the university and the community is thereby conducted through the acquisition of knowledge in a two-way street: we learn and teach, moved by the desire of building a more just and humanitarian city, a city with environmentally sustainable and educational spaces.

\footnotetext{
${ }^{8}$ 2013, Interview registered by Boucinhas and Lima.
}

\section{A new perspective: the creation of the Educator Park}

After an experience so valuable in its accumulation of information and desires, the challenge was to make sure the work continued at other levels of implementation. Following the Charrette and hoping for the continuation of the school-university partnership, two students at FAU-USP decided to conduct their final undergraduate work with projects capable of making the wishes and demands of the school community a reality, in technically achievable proposals. Paula Martins Vicente planned a School-Park project (the relationship of the school with its immediate surrounding park) and Vanessa Chinen worked on an idea for a Park-School (the park itself, a goldmine of educational opportunities, a "school" in itself); despite the different focuses, the two students worked on broader relationships between school-park-city. (Vicente, 2012).

These two studies resulted in a further development, a new question: why not discuss with the City Hall the possibility of implementing a project, a synthesis of this whole valuable process? Representatives from the school, parents of students, and the university contacted the Municipal Education Department (SME) to try to convince them of the relevance of a School-Park and the expansion of pedagogical opportunities within the Park (Park-School). The SME not only welcomed the ideas being discussed, but also scheduled a visit by the Mayor of Sao Paulo himself to the Pinheirinho d'Água Park and the EMEF - Rogê Ferreira to hear about and discuss the projects. 
Within the scope of the discussions that arose, in 2013 (from a suggestion by the City Hall itself), the idea of a synthesis project of the contributions made throughout this process in over 20 years from Charrettes, undergraduate concluding courses, research studies, etc. - brought a new challenge: that of gathering all the public schools located in the area near the Park to work on their political-pedagogical projects, with one of the focuses being the Pinheirinho d'Água park.

The idea of an educator-park was born, a new proposal in this two-decade-long participatory process, a new front in the struggle. A project was therefore developed from the opportune viewpoint of the synthesis and improvement of didactic resources within the park area. Twenty-four schools surrounding the area participated, together with university and city government departments. The tripod of residents, teaching and government institutions was further strengthened, and the schools became engaged in an intense and motivated process of conducting projects within the park (even though this latter continued to lack proper maintenance care).

The starting point of planning the new project had the premises constructed in the process as its conceptual basis, when it was decided that the educator-park Pinheirinho d'Água should:

- have its original functions as a municipal public park guaranteed, for leisure, recreation, sports, and peaceful mutual sharing open to the whole population.

- have a new uses program as indicated by the syntheses of the participatory process with educators, children, and adolescents from the area.

- benefit from the participation of educators, children, and adolescents who will over time supply the new park with pedagogical, creative and recreational proposals.

- create a dialogue with the original executive project for needed and/or desired alterations.

- protect the areas of permanent preservation (APPs) guaranteeing the provision of current environmental services.

- preserve its predominant landscape identity of wet and/or vegetation-covered flatlands and forested slopes.
At the moment of writing this article, the popular forces that constituted this process (schools that surround the park, social movements, and members of the Park Management Council, elected by the local population) are fighting for their proposals to be budgeted and implemented by Municipal Departments. The struggle continues...

\section{Challenges in a theoretical construct}

The cooperative process of building the public space presented here clamors for deeper reflection, in a search to transcend the empirical and the analytical, and construct a framework of theoretical bases and of synthesis.

In this article, the need for deeper reflection has, nonetheless, resulted in a preliminary outline of what could in the future become the structure of a critical theory referenced in this experience. We will therefore seek to raise some questions that may lead us to reflection, taking as a basis the processes herein spoken of, cross-referenced with the thinking of the selected authors.

As a starting point, we can identify in Guattari (2014) a support basis for beginning this journey (from the empirical to the theoretical), in which he articulates a rationale for synthesis when formulating his proposal of the Three Ecologies - the environmental, the social, and the subjectivities; one can see the Pinheirinho d'Água Park through the prism of these three proposed focuses, as we have attempted in this article. In terms of the environmental dimension, it is of utmost urgency that public policies confront a responsible management of such important remnants of the city's biophysical foundation; at a time of serious crisis in water resources in the city of Sao Paulo, streams such as the Pinheirinho d'Água continue to be polluted and illegally occupied, while springs and other water courses are victims of serious environmental crimes.

From the social viewpoint and the production of subjectivities, it is equally reasonable to think of the process of the Park as the legitimacy which Guattari calls molecular revolutions - "[...] new micro-political and micro-social practices, new solidarities, a new lightness together with new esthetical and analytical practices in the formation of the unconscious [...]" (Guattari, 2014 , p. 35). After all, it was popular mobilization caused by a desire for a qualified habitat that led to the construction (even if partially) of the Park. 
We can also infer, in a future perspective of a highly educated, politically engaged and cooperative society, that it would be appropriate to

[...] allow particular cultures to develop as they invent themselves, at the same time as other contacts of citizenship [...] so that singularity, the exception, the rarity, work together with a state order that is the least intrusive possible. (Guattari, 2014, p. 35).

Nevertheless, the question raised here is: how can this occur in a country whose social inequalities are due precisely to the absence of the State, the producer of urban peripheries lacking the most basic of guaranteed rights? At present, the attention paid by the public authorities to the periphery of the metropolitan area of Sao Paulo is negligible, provoking its expansion with a contingent worsening of living conditions.

We can here pose another question: what is the reach and efficacy of public policies in improving the social conditions of these marginalized populations, within a system that has produced such deep urban inequalities, housing deficits, etc.? Here the thinking of Ermínia Maricato is useful:

As citizens of a country on the margins of capitalism, in which the new nomenclatures are defined by the mainstream, Brazilian cities carry a burdensome heritage. Social inequality, one of the greatest in Latin America, the slavery that existed up to little more than a century ago are characteristics of that added to a patrimonialist State and the universe of 'politics of favors'. In what form do these characteristics appear in cities?...We will prioritize the fact that large parts of our cities are built by the inhabitants themselves in areas that have been illegally occupied - many of which are environmentally fragile - or acquired from illegal lot sellers. No architects or engineers are involved in the construction of these subdivisions, nor is there any observance of city planning legislation or of any other legislation, or even in the resolution of (frequent) conflicts, in which no lawyers, court judges or courts have been present. It is a workforce that cannot be classified within the legal private residential market, which in turn (and due to this) is highly speculative. It is therefore a cheap workforce, segregated and excluded from the legitimate city. Just as we are experiencing an industrialization driven by low wages, we can also say that we are experiencing an urbanization driven by low wages. The improvement of these neighborhoods is an inexhaustible source of old political cronyism, votes are exchanged for street paving, public lighting, a health post, a bus route, etc. (Maricato, 2013, p. 20-21).

In similar fashion, Harvey (2014, p. 29-30) asks: "What will we do faced with immense concentrations of wealth, privileges and consumerism, contrasting with the maelstrom of what even the United Nations describes as a Planet of favelas?". In the last resort, urban reform - and even Guattari's inter-subjective proposal - encounter obstacles in the structural problems of an economic and political nature that need to be faced if there is to be an effective redistribution of income capable of producing social mobility.

Harvey's position is, therefore, far from ignoring the importance of contemporary social movements and identifying opportunities for political action. A heterodox Marxist, he has written at least two recent works corroborating this affirmation: the article "The Freedom of the City" (2013) and the book "Rebel Cities" (2014) ; in them, he attributes to cities the principal role in anti-capitalist resistance and in the transformation of the world and its inhabitants, crediting social movements for the human rights won:

[...] the question of what kind of city we want cannot be separated from the kind of people we want to be, what kind of social relationships we seek, what relationships with nature give us greatest satisfaction, what kind of life we want to live. The right to the city is, therefore, much more than a right to individual or group access to the resources that the city embodies: it is a right to change and reinvent a city more in accordance with our deepest desires. (Harvey, 2014, p. 28).

The fundamental question that emerges, in our point of view, from comparing the ideas of Felix Guattari with those of David Harvey shown here is that, despite their divergences, they recognize the role of urban social struggles in the transformation of the contemporary world, giving value to the subject, their desires, and their subjectivity in this process. Harvey suggests, however, a grassroots and transformational movement by demanding the creation of urban public 
spaces, developing the anti-hegemonic, molecular character of Guattari's formulation. In our thinking in this case study, Harvey's preoccupation with struggles for individual causes, in which his legitimacy weighs, has not resulted in what would be a grave mistake by becoming self-centered, but rather favors an effective institutional and social transformation, capable of confronting the real obstacles frustrating a needed and radical urban reformation.

What approaches and actions have a real chance of connecting rhizomatically as Guattari suggests, and being real agents of change, of political and economic realities, moving toward a more socially just and more ecologically balanced world? Guattari's 'ecosophic' proposal indicates a political direction to follow along three lines: the environmental, the social, and that of subjectivities. The struggle to build the Pinheirinho d'Água Park should, therefore, be inserted into the broadest and deepest context of the right to the city, in the sense proposed by Harvey, equivalent to "[...] claiming some kind of configuring power over the processes of urbanization, over the way in which our cities are made and remade that presupposes doing it in a radical, fundamental way." (Guattari, 2014, p. 30).

\section{Towards a qualified landscape for all}

This whole planning and construction process for a public park in the periphery of Sao Paulo taught many lessons to its participants, creating an opportunity for effective realization of the praxis and the struggle for the transformation of everyday space. It also mobilized subjectivities in the sense of "the right to have rights" beyond what is offered to the "invisible" residents living on the edges of urban peripheries.

For many, it created the perception that the right to a city should include, equally, the right to landscape, in what the latter represents in terms of the qualification of an urban space; landscape, not as an accessory fact to questions of planning and project, but as a dimension necessary for the creation of a more humanized and esthetically qualified habitat. To the objective functions of the city and to the vital fluxes of the environment, the idea of landscape adds valuable possibilities for the fruition of the urban space, contributing to it becoming a place in which the inhabitants are more able to develop relations of affection and belonging.
This is a discussion that is still far from being held in the forgotten peripheries of Brazil, as important as the discussion of the immaterial heritage, art, and culture. Hostages to their immediate needs, they appear to have to settle for services for the essential functions of survival, leaving in the background demands for: sidewalks useable by people with special needs, urban trees for shelter, improved microclimates and the cooling of urban heat islands, clean running streams, visible and accessible qualified spaces for meeting and leisure, places that are beautiful, safe and welcoming. Fortunately, we can still identify in the cracks of everyday life, educators and social movements in the struggle for the qualification of the city through the creation of public open spaces, among other things.

In our experience, a collective process of landscape design, such as in the Pinheirinho d'Água Park, has been a fundamental ally in the construction of new subjectivities through the potential it represents for the creation of insurgent spaces capable of transforming the abrasive contours of reality.

Humans only overcame their immanence by being a being of projects. Pro jacto means precisely "going forward". And what makes us a being of projects is this drive for life, or the pulse of life within us. The actions of humankind aim to concretize the vital pulse that programmed us to refuse death and extinction. We invented politics, economics, and society. We interpret the beauty of nature and create beauty where there was none, through art and culture. And, in truth, all this was, above all, a 'pro-ject'. (Abdalla, 2004, p. 140-141).

The landscape, as a totality that expresses itself, is perceived and lived offering itself as a political instrument for reading the world and also as a mobilization of subjectivities. If planned collectively, it can help in the creation of revolutionary processes that lead to the players involved becoming the subjects of their own story.

\section{References}

Abdalla, M. (2004). O principio da cooperação: por uma nova racionalidade (2nd ed.). São Paulo: Paulus.

Boucinhas, C., \& Lima, C. P. C. S. (2013). Parque pinheirinho d'água: a luta por reconhecimento e visibilidade. Pós: 
Revista do Programa de Pós-Graduação em Arquitetura e Urbanismo da FAUUSP, 20(33), 14-34.

Freire, P. (2004). Pedagogia da autonomia: saberes necessários a pratica educativa (30th ed.). São Paulo: Paz e Terra.

Google Earth. (2015). Foto aérea. Digital Globe, 19 de abril de 2015.

Guattari, F. (2014). As três ecologias (21st ed.). Campinas: Papirus.

Harvey, D. (2014). Cidades rebeldes: do direito a cidade a revolução urbana (1st ed.). São Paulo: Martins Fontes.

Holloway, J. (2010). Crack capitalism (1st ed.). New York: Pluto Press.

Instituto Brasileiro de Geografia e Estatística - IBGE. (2015). Mapa do Brasil: Estados e Capitais. Brasília. Retrieved in 10 June 2015, from http://www.baixarmapas.com.br/ mapa-do-brasil-estados-e-capitais/
Lennertz, B., \& Lutzenhiser, A. (2003). Charrettes 101: dynamic planning for community change. In J. H. Carr (Ed.), Building Blocks. Washington: Fannie Mae Foundation.

Luymes, D., \& Proft, J. (2002). Sustainable watersheds: urban landscape design for low-income settlements, the pintassilvo community design charrette, Santo André, Brasil. Vancouver: University of Britsh Columbia.

Maricato, E. (2013). É a questão urbana, estúpido! In C. Vainer et al. Cidades rebeldes: passe livre e as manifestações que tomaram as ruas do Brasil (1st ed., p. 31). São Paulo: Boitempo Editorial \& Carta Maior.

Universidade de São Paulo - USP. Faculdade de Arquitetura e Urbanismo - FAU. Laboratório Paisagem Arte e Cultura LABPARC. (2002). Charrette 2002. São Paulo. Arquivo digital.

Vicente, P. M. (2012). A escola como um parque e o parque como uma escola. São Paulo: FAU-USP.

Received: June 15, 2015

Approved: Oct. 05, 2015 